\title{
STUDI PENGELOLAAN AIR BERSIH DI KAWASAN INDUSTRI JABABEKA KABUPATEN BEKASI
}

\author{
Faeruzy Arnandi, Henita Rahmayanti, Gina Bachtiar
}

\begin{abstract}
Abstrak
Penelitian ini bertujuan untuk mengetahui bagaimana pengelolaan air bersih yang ideal untuk memenuhi kepuasan pelanggan (industri dan perumahan) dikawasan industri Jababeka. Penelitian ini dilakukan di Kawasan Industri Jababeka pada WTP I dan WTP II mulai dari bulan Mei sampai dengan bulan Juli 2011.

Dalam penelitian ini menggunakan Metode Deskriptif Kualitatif, dengan populasi adalah seluruh pelanggan air bersih (industri dan perumahan) di Kawasan Industri Jababeka. Sedangkan jumlah sampel adalah 10 pelanggan industri dan 33 pelanggan perumahan dengan teknik pengambilan sampel menggunakan simple random sampling.Instrument yang digunakan adalah kuisioner, wawancara dan observasi untuk menjaring data mengenai kualitas dan kuantitas air bersih di WTP dan pendapat pelanggan mengenai air bersih di Kawasan Industri Jababeka. Parameter pokok yang diukur adalah tingkat $\mathrm{pH}$ dan Kekeruhan/turbidity yang terdapat di tempat pengolahan dan pipa distribusi di WTP.

Hasil penelitian didapat bahwa terdapat kekurangan jika dibandingkan dengan standar kualitas air bersih yang telah ditetapkan di Kawasan Industri Jababeka dengan kenyataan yang sebenarnya. Namun, untuk pemenuhan air bersih kawasan pelanggan industri, berdasarkan presentase menunjukkan bahwa kualitas air masih belum memenuhi kebutuhan dan kepuasaan pelanggan. Sementara dari segi kuantitas, pemenuhan air bersih untuk kawasan pelanggan perumahan masih belum memenuhi kepuasaan pelanggan, debit air yang dihasilkan masih harus ditingkatkan. Namun, untuk pemenuhan kuantitas air bersih di kawasan industri sudah memenuhi kepuasaan pelanggan. Setelah dilakukan identifikasi tempat pengelolaan, hasil perbandingan frekuensi menunjukkan, untuk instalasi pengolahan air tidak terjadi penurunan kualitas (kekeruhan dan peningkatan $\mathrm{pH}$ ) dan kuantitas (volume dan debit air). Penurunan terjadi pada bagian pipa distibusi, baik kualitas dan kuantitas. Untuk meminimalisir penurunan tersebut, perlu dilakukan pengawasan yang ketat pada saat melakukan flushing.
\end{abstract}

Kata Kunci : pengelolaan air bersih, kawasan industry

\begin{tabular}{|l|c|r|}
\hline Faeruzy Arnandi & Dra. Henita Rahmayanti, M.Si & Dr. Gina Bachtiar, MT \\
Alumni Jurusan Teknik Sipil & Staff Pengajar Jurusan Teknik Sipil & Staff Pengajar Jurusan Teknik Sipil \\
Fakultas Teknik & Fakultas Teknik & Fakultas Teknik \\
Universitas Negeri Jakarta, & Universitas Negeri Jakarta, 13220 & Universitas Negeri Jakarta, 13220 \\
\hline
\end{tabular}




\section{PENDAHULUAN}

Air merupakan bagian penting dari sumber daya alam yang mempunyai karakteristik unik dibandingkan dengan sumber daya alam lainnya. Air merupakan sumber daya terbarukan dan dinamis yang akan selalu datang berupa hujan. Air secara alami mengalir dari hulu ke hilir, dari daerah yang lebih tinggi ke daerah yang lebih rendah. Air mengalir di atas permukaan tanah, namun juga mengalir di dalam tanah.

Soemarwoto (Soemarwoto 2001:34, diacu dalam Razif 2006) menjelaskan bahwa air adalah kebutuhan yang utama untuk kehidupan. Kebutuhan air tidak saja menyangkut kuantitas, melainkan juga kualitas. Kuantitas atau jumlah air yang tersedia sangat berkaitan dengan iklim, terutama curah hujan. Curah hujan pada umumnya tidak terbagi rata sepanjang tahun, yaitu ada musim hujan dan musim kemarau. Karena itu, pasokan air juga tidak merata, yaitu banyak pada musim hujan dan sedikit pada musim kemarau. Kuantitas air yang tersedia dipengaruhi oleh luas lahan.

Dari segi kualitas, air yang digunakan harus memenuhi kualitas sesuai dengan peruntukannya dan masing-masing peruntukan mempunyai baku mutu. Effendi (2003:30) menyatakan bahwa kualitas air dipengaruhi 3 komponen utama, yaitu komponen hidrologi, komponen fisika-kimia dan komponen biologi. Penilaian kualitas suatu badan air harus mencakup ketiga komponen tersebut.

Pertambahan penduduk, peningkatan urbanisasi, pertumbuhan industri, perkembangan ekonomi, dan peningkatan standar hidup adalah sebagian dari faktor-faktor meningkatnya kebutuhan air minum bagi manusia. Untuk keperluan tersebut diharapkan bahwa sumber air baku yang akan digunakan mempunyai kualitas dan kuantitas yang memenuhi persyaratan dan secara terus menerus tersedia untuk dapat digunakan melayani kebutuhan pada masa kini hingga masa yang akan datang sesuai dengan keinginan manusia.

Ketersediaan air yang cukup secara kuantitas, kualitas, dan kontinuitas sangat penting untuk kelangsungan hidup manusia. Untuk itu diperlukan suatu instalasi pengolahan air (IPA) guna menunjang kelancaran distribusi air pada masyarakat. Pemilihan unit operasi dan proses pada IPA harus disesuaikan dengan kondisi air baku yang digunakan. Salah satunya instalasi pengolahan air (IPA) bersih yang ada di kawasan industri dan perumahan JABABEKA.

Sebagai salah satu kawasan industri termuka di wilayah Kabupaten Bekasi, JABABEKA merupakan salah satu pusat industri yang sangat mementingkan kelengkapan dalam infrastuktur. Salah satu infrastruktur yang diutamakan adalah Instalasi Pengolahan Air Bersihnya. Untuk 
kawasan industri JABABEKA ini, instalasi pengolahan air bersih yang ada, diolah secara mandiri, dan terpadu. Hal ini dikarenakan, para investor yang menaruh sahamnya di kawasan industri JABABEKA, menginginkan fasilitas air bersih yang cepat, efektif, dan teruji secara laboratoris.

Dengan menggunakan sistem Water Treatment Plant (WTP), air bersih yang telah diolah didistribusikan ke seluruh kawasan industri dan perumahan JABABEKA dengan menggunakan metode dan sistem tertentu. Namun, meskipun sistem pengelolaannya sudah berjalan baik, pihak WTP masih menemui kritikan dari pihak pelanggan/tenant, baik perumahan maupun industri. Mereka mengeluhkan terjadinya penurunan kualitas dan kuantitas air bersih yang didistribusikan ke masing-masing pelanggan. Dampak yang dihasilkan persoalan ini, adalah banyaknya pelanggan yang tidak mendapatkan pasokan air bersih secara maksimal,. Hal ini tentu menjadi masalah tersendiri bagi pihak pengelola WTP selaku penanggung jawab pengelolaan air bersih ini, yaitu bagaimana pengelolaan air bersih yang ideal untuk memenuhi kebutuhan air bersih kesemua pelanggan (industri dan perumahan) di kawasan Jababeka?

Pengelolaan diartikan sebagai suatu rangkaian pekerjaan atau usaha yang dilakukan oleh sekelompok orang untuk melakukan serangkaian kerja dalam mencapai tujuan tertentu. Menurut Wardoyo (1980:41) memberikan definisi sebagai berikut pengelolaan adalah suatu rangkai kegiatan yang berintikan perencanaan ,pengorganisasian pengerakan dan pengawasan dalam mencapai tujuan yang telah ditetapkan sebelumnya. Menurut Harsoyo (1977:121) pengelolaan adalah suatu istilah yang berasal dari kata "kelola" mengandung arti serangkaian usaha yang bertujuan untuk mengali dan memanfaatkan segala potensi yang dimiliki secara efektif dan efisien guna mencapai tujuan tertentu yang telah direncanakan sebelumnya. Dari uraian diatas dapatlah disimpulkan bahwa yang dimaksud dengan pengelolaan adalah suatu rangkaian kegiatan yang berintikan perencanaan, pengorganisasian, penggerakan dan pengawasan yang bertujuan menggali dan memanfaatkan sumber daya alam yang dimiliki secara efektif untuk mencapai tujuan organisasi yang telah ditentukan.

Standar kualitas air bersih yang ada di Indonesia saat ini menggunakan :

1. Permenkes RI No. 416 / Menkes / Per / IX / 1990 tentang Syarat-Syarat dan Pengawasan Kualitas Air

2. PP RI No. 82 Tahun 2001 tentang Pengelolaan Kualitas Air dan Pengendalian Pencemaran Air

Sesuai dengan Keputusan Presiden (Keppres) Republik Indonesia nomor 53 tahun 1989 yang telah diperbaiki dengan keppres nomor 41 tahun 1996 tentang Kawasan Industri, yang 
dimaksud dengan kawasan industri adalah tempat pemusatan kegiatan industri yang dilengkapi dengan prasarana, sarana, dan fasilitas penunjang lainnya yang dikembangkan dan dikelola oleh perusahaan kawasan industry yang telah memiliki izin usaha kawasan industri, pembangunannya bertujuan untuk :

a. Mempercepat pertumbuhan industri

b. Memberikan kemudahan bagi kegiatan industri

c. Menyediakan fasilitas lokasi industri yang berwawasan lingkungan

Kawasan Jababeka adalah kawasan terintegrasi yang menawarkan kawasan bisnis dan pemukiman eksklusif dengan lokasi strategis berkonsep lingkungan. Kawasan mandiri ini berkembang pesat, lengkap dengan berbagai fasilitas penunjang dan potensi investasi. Semua hal tersebut menjadikan Kota Jababeka sebagai tempat tinggal pilihan para profesional, intelektual dan pebisnis. (Sunarjo 2007)

Kepuasan pelanggan (Customer Satifaction) atau sering disebut juga dengan Total Customer Satisfaction menurut Barkelay dan Saylor (1994:82, diacu dalam Yuliarmi 2007) merupakan fokus dari proses Costomer-Driven Project Management (CDPM), bahkan dinyatakan pula bahwa kepuasan pelanggan adalah kualitas. Begitu juga definisi singkat tentang kualitas yang dinyatakan oleh Juran (1993:3) bahwa kualitas adalah kepuasan pelanggan. Menurut Kotler yang dikutip Tjiptono (1996:146) bahwa kepuasan pelanggan adalah tingkat perasaan seseorang setelah membandingkan kinerja (atau hasil) yang dirasakan dengan harapannya. Jadi, tingkat kepuasan adalah fungsi dari perbedaan antara kinerja yang dirasakan dengan harapan. Kualitas termasuk semua elemen yang diperlukan untuk memuaskan tujuan pelanggan, baik internal maupun ekternal, juga termasuk tiap-tiap item dalam produk kualitas, kualitas layanan, performance, availibility, durability,aesthetic, reability, maintainability, logistic, supprtability, customer service, training, delivery, billing, shipping, repairing, marketing, warranty, dan life cycle cost.

Melalui komunikasi, baik antar pelanggan maupun dengan supplier akan menjadikan harapan bagi pelanggan terhadap kualitas produk yang akan dibelinya. Pemahaman terhadap harapanharapan pelanggan oleh supplier merupakan input untuk melakukan perbaikan dan peningkatan kualitas produk, baik barang maupun jasa. Pelanggan akan membandingkan dengan produk jasa lainnya. Bilamana harapan-harapannya terpenuhi, maka akan menjadikannya pelanggan loyal, puas terhadap produk barang atau jasa yang dibelinya. Sebaliknya, bilamana tidak puas, supplier akan ditinggalkan oleh pelanggan. 
Kunci kepuasan pelanggan berkaitan dengan kepuasan terhadap penilaian produk barang dan jasa. Kerangka kepuasan pelanggan tersebut terletak pada kemampuan supplier dalam memahami kebutuhan, keinginan dan harapan pelanggan sehingga penyampaian produk, baik barang maupun jasa oleh supplier.

Dengan semakin berkembangnya lingkup industri dan perumahan di Indonesia , tak terhindarkan lagi bahwa masyarakat semakin memikirkan standar kualitas yang tinggi baik dari segi kesehatan ,ekonomi dan segi yang lain. Oleh karena itu pihak yang terkait perlu memikirkan aspek apa saja yang bisa dikembangkan baik segi teknologi maupun ekonomi.

Instalasi Pengolahan Air (IPA) Bersih merupakan salah satu sarana infrastruktur yang memiliki peran cukup penting dalam memenuhi kebutuhan air bersih di suatu kawasan industri dan perumahan, tak terkecuali di kawasan industri dan perumahan JABABEKA. dengan menerapkan sitem Water Ttreatment Plant (WTP), Instalasi Pengolahan Air (IPA) Bersih yang dilakukan secara terpadu dan mandiri ini mencakup segala kebutuhan air bersih baik untuk industri dan perumahan yang terdapat di kawasan JABABEKA.

Sedikitnya ada beberapa faktor yang menyebabkan penurunan kualitas dan kuantitas air bersih : perilaku pemakaian air bersih pada individu pelanggan, zona distribusi yang berbedabeda, baik pelanggan industri maupun perumahan. Perilaku pemakaian bisa terjadi mengingat konsumsi dari tiap kepala pada satu rumah atau industri berbeda-beda. Zona distribusi yang berbeda-beda menyebabkan aliran air yang dipasok juga mengalami perbedaaan, hal ini secara tidak langsung mempengaruhi pasokan air bersih ke masing-masing zona.

Terjadinya masalah penurunan kualitas dan kuantitas air bersih tentu menjadi problematika tersendiri bagi pihak penanggung jawab kawasan Jababeka, terlebih lagi, ini menyangkut tingkat kepuasaan pelanggan di kawasan Jababeka yang mulai berkembang. Studi mengenai pengelolaan air bersih, yang didalamnya juga mencakup parameter kualitas, kuantias dan tingkat kebutuhan air bersih, kiranya dapat dilaksanakan dengan baik dan teliti. Tentunya butuh kordinasi yang intensif antara penulis, penanggung jawab WTP dan pelanggan mengenai studi ini, karena kordinasi ini nantinya akan sangat bermanfaat bagi pihak-pihak yang terkait dalam menangani masalah tersebut.

\section{METODA}

Tujuan penelitan ini adalah untuk mengidentifikasi pengelolaan air bersih pada instalasi pengolahan air (IPA) yang digunakan di kawasan Jababeka serta mengetahui tingkat kepuasaan air bersih pelanggan industri dan perumahan sehingga menjadi salah satu alternatif untuk 
meningkatkan mutu dari penyedia jasa Instalasi Pengolahan Air (IPA) bersih. Penelitian dilakukan di Kawasan Industri JABABEKA, Cikarang, Kabupaten Bekasi-Jawa barat, khususnya di tempat Instalasi Pengolahan Air (IPA) Bersih atau Water Treatment Plant (WTP). Penetapan kawasan industri Jababeka sebagai lokasi penelitian atas dasar bahwa kawasan tersebut merupakan kawasan industri terbesar di Indonesia dan Asia Tenggara dengan jenis industri yang bervariatif serta berpotensi untuk dikembangkangkannya Instalasi Pengolahan Air (IPA) Bersihnya.

Lokasi penelitian adalah tempat pengelolaan air bersih atau WTP (Water Treatment Plant) I dan WTP II di dalam satu kawasan industri dan perumahan Jababeka yang terintegrasi secara terpadu ke masing - masing pelanggan.

Metode yang digunakan dalam melakukan penelitian adalah secara deskriptif kualitatif. pendekatan kualitatif digunakan untuk memahami nilai suatu makna. Sementara pendekatan deskriptif merupakan metode yang digunakan untuk membuat suatu deskripsi atau gambaran secara sistematis, faktual, akurat, mengenai fakta-fakta, sifat-sifat, serta hubungan antar fenomena yang diselidiki (Nazir, 1988:63, diacu dalam Arikunto 1990). Menurut Sevilla (1993:7176, diacu dalam Arikunto 1990), metode penelitian deskriptif dirancang untuk mengumpulkan informasi dengan tujuan memberi gambaran yang lebih jelas tentang sifat suatu keadaan yang sedang berlangsung saat penelitian dilakukan, dan memeriksa sebab-sebab dari suatu gejala tertentu. Jenis penelitian deskriptif antara lain: studi kasus, survei, penelitian pengembangan, penelitian lanjutan, analisis dokumen, dan analisis kecenderungan.

Populasi pada penelitian ini adalah pelanggan (industri atau perumahan) yang berada di kawasan JABABEKA. Berdasarkan data dari PT. Jababebka Infrastruktur (Developer), terdapat 1400 pelanggan perusahaan industri dan 10.359 pelanggan perumahan yang menggunakan fasilitas air bersih WTP di Jababeka. Sample pada penelitian ini adalah pelanggan air bersih. Diambil sampel 30 pelanggan perumahan dan 10 pelanggan industri kawasan JABABEKA.

Tabel 1. Rincian Pengambilan Sampel

\begin{tabular}{|c|c|c|c|}
\hline No & Responden & Jumlah Populasi & Jumlah Sampel \\
\hline 1 & Pelanggan Industri (Perusahaan) & 1400 & 10 \\
\hline 2 & Pelanggan Perumahan & 10.359 & 30 \\
\hline \multicolumn{2}{r|}{ Total } & 11.795 & 40 \\
\hline
\end{tabular}


Untuk mendapatkan data dan informasi yang memadai, metode yang lazim digunakan adalah survey, kuesioner, wawancara (interview) terbimbing maupun bebas dan mendalam, analisa data sekunder (misalnya data dari dokumen yang relevan) dan melakukan observasi langsung ke lapangan sebagai data primer (Samudra, 1994:27, diacu dalam Utari 2010).

Dalam penelitian ini, pengumpulan data primer dilakukan dengan cara observasi langsung ke lapangan (dalam hal ini ke tempat Instalasi Pengolahan Air (IPA) Bersih) dan juga melakukan wawancara terstruktur maupun tidak terstruktur dan penyebaran kuesioner. sedangkan pengumpulan data sekunder dengan cara studi kepustakaan atas teori yang ada, baik dari referensi skripsi, tesis, atau hasil penelitian sejenis yang telah dilakukan, dokumen atau arsip baik yang telah dipublikasikan maupun tidak, dan perundang-undangan atau peraturan yang berlaku.

\section{HASIL DAN PEMBAHASAN}

Responden yang menjadi obyek penelitian adalah pelanggan perumahan dan pelanggan industri yang menggunakan fasilitas air bersih di kawasan Jababeka. Air bersih yang dialirkan untuk pelanggan perumahan di Kawasan Industri Jababeka (KIJ) II dibedakan menjadi 3 zona pelayanan yang sudah ditetapkan oleh pengembang (PT. Jababeka Infrastruktur).

Tabel 2. Pebandingan Zona Pelayanan Air Bersih WTP II Kawasan Jababeka (Pelanggan Perumahan)

\begin{tabular}{|c|c|c|c|}
\hline \multirow{2}{*}{ No } & \multirow{2}{*}{ Wilayah } & \multicolumn{2}{|c|}{ Zona Pelayanan } \\
\cline { 3 - 4 } & & Luas Area $\left(\mathbf{m}^{2}\right)$ & $\%$ \\
\hline 1 & Utara/Zona Pelayanan 1 & 466.504 & 33.25 \\
\hline 2 & Timur/Zona Pelayanan 2 & 679.781 & 48.46 \\
\hline 3 & Selatan/Zona Pelayanan 3 & 256.499 & 18.28 \\
\hline \multicolumn{2}{|c|}{ Total } & 1402.784 & 100 \\
\hline
\end{tabular}

Tabel 3. Zona Pelayanan Air Bersih WTP I Kawasan Jababeka (Pelanggan Industri)

\begin{tabular}{|c|c|c|c|}
\hline \multirow{2}{*}{ No } & \multirow{2}{*}{ Wilayah } & \multicolumn{2}{|c|}{ Zona Pelayanan } \\
\cline { 3 - 4 } & & Luas Area (Ha) & $\%$ \\
\hline 1 & Kawasan Industri Jababeka (KIJ) I & 790 & 77.45 \\
\hline 2 & Kawasan Industri Jababeka (KIJ) II & 230 & 22.55 \\
\hline \multicolumn{2}{c|}{ Total } & 1020 & 100 \\
\hline
\end{tabular}


Instalasi Pengolahan Air bersih di WTP I merupakan salah satu fasilitas penunjang yang berfungsi untuk mengolah dan mendistribusikan air bersih ke seluruh pelanggan industri. Dalam pengolahannya, air bersih yang masuk ke WTP I mengalami berbagai proses pengolahan. Berikut alur pengolahannya :

1. Prasedimentasi

Pada proses ini air baku yang berasal dari Sungai Tarum Barat dialirkan melalui pipa dengan panjang $\pm 3 \mathrm{~km}$ menuju lorong prasedimentasi untuk dilakukan proses aerasi (pencampuran air bersih dengan gas $\mathrm{Cl}_{2}$ / Desifektan) untuk membunuh kuman dan bakteri yang terdapat dalam air baku. Teknik pencampuran dilakukan dengan blower yang terdapat didasar bak. Setelah proses pencampuran kemudian kotoran yang besaran disaring dengan screen mesh (Jaring yang terbuat dari stainless stell). Kemudian air dipompa menuju ke flokulator.

\section{Flokulator}

Air yang telah disaring, kemudian dipompa menuju bak flokulator, namun sebelum sampai di flokulator, dilakukan proses injeksi dengan bahan kimia (PAC/Poli Alumunium Chloride) yang merupakan koagulant yang berfungsi untuk menjernihkan air. Proses injeksi dilakukan dilakukan didalam pipa dengan menggunakan static mixer. PAC disimpan dalam tabung besar stock tank coagulant. Setelah itu didalam flokulator dilakukan pengadukan secara lambar agar kotoran yang masih ada saling membentuk flok - flok / lumpur secara sempurna.

\section{Clarifier/Settling Zone}

Setelah proses pembentukan flok sempurna, kemudian air menuju ke clarifier. Di Clarifier ini, flok - flok yang sudah terbentuk sempurna kemudian dipisahkan dari air dengan menggunakan mixer yang besar. didalam clarifier terdapat scrapper (karet panjang yang menyerupai gerigi) yang berfungsi untuk mengumpulkan flok / lumpur didasar. Dalam clarifier ini juga dilakukan pemeriksaan $\mathrm{pH}$ dan kekeruahan/turbudity secara manual dengan menggunakan alat turbiditymeter dan $\mathrm{pH}$ meter. Air bersih yang sudah dipisahkan dari flok, kemudian menuju sand filtration.

\section{Sand Filtration / Gravity Sand Filter (GSF)}

Air yang berada di GSF, kemudian disaring kembali dengan menggunakan bahan pasir silica agar kotoran-kotoran yang lebih kecil dapat tersaring. Dalam GSF ini, dilakukan proses backwash (proses pemisahan air yang masih mengandung kotoran menuju flokulaltor kembali). Proses ini sebagian dilakukan secara otamatis dan manual. Dari GSF, kemudian air dialirkan menuju ke final reservoir. 


\section{Treated Water Reservoir}

Air yang telah melalui proses penyaringan secara kontinu, kemudian ditampung didalam reservoir. Merupakan bak besar yang dapat menampung air bersih dengan kapasitas 5000 $\mathrm{m}^{3}$. Air bersih yang berada di reservoir sudah bisa didistribusikan ke seluruh pelanggan dengan dilakukan pemeriksaan terhadap $\mathrm{pH}$ dan kekeruhannya.

6. Water Supply Pump Station

Air bersih yang telah diperiksa, kemudian didistribukan ke seluruh pelanggan dengan menggunakan pompa udara berskala besar / water supply pump dengan sebelumnya dilakukan pengaturan tekanan air yang dikeluarkan.

Dalam melakukan pengamatan terhadap kualitas air bersih, terdapat 2 tempat yang dijadikan sampel penelitian, yakni :

1. Instalasi Pengolahan Air Bersih

Pengujian menggunakan alat turbiditymeter untuk mengukur tingkat kekeruhan dan alat $\mathrm{PH}$ meter untuk mengukur tingkat $\mathrm{PH}$.

2. Pipa Distribusi Pelanggan Industri

Pengujian dilakukan di laboratorium, sampel air bersih diambil di pipa distribusi di kawasan industri Jababeka. Hal ini bertujuan agar kualitas air yang dihasilkan bisa ditelusuri mulai dari pengolahan sampai pendistribusiannya.

Tabel 4. Kualitas Air Bersih di Instalasi Pengolahan Air WTP I

\begin{tabular}{|c|c|c|c|c|}
\hline \multirow{2}{*}{ No } & \multirow{2}{*}{ Hari Penelitian } & \multirow{2}{*}{$\begin{array}{c}\text { Lokasi } \\
\text { Penelitian }\end{array}$} & \multicolumn{2}{|c|}{ Parameter Pokok } \\
\hline & & & $\mathrm{PH}$ & NTU \\
\hline \multirow{3}{*}{1} & \multirow{3}{*}{ Selasa, 14 Juni 2011} & Clarifier-1 & 7,34 & 1,72 \\
\hline & & Clarifier-2 & 7,27 & 1,47 \\
\hline & & WSP & 7,34 & 0,19 \\
\hline \multirow{3}{*}{2} & \multirow{3}{*}{ Rabu, 15 Juni 2011} & Clarifier-1 & 7,21 & 2,70 \\
\hline & & Clarifier-2 & 7,16 & 3,04 \\
\hline & & WSP & 7,30 & 0,26 \\
\hline \multirow{3}{*}{3} & \multirow{3}{*}{ Kamis, 16 Juni 2011} & Clarifier-1 & 6,97 & 3,72 \\
\hline & & Clarifier-2 & 7,06 & 3,27 \\
\hline & & WSP & 7,14 & 0,89 \\
\hline & \multicolumn{2}{|c|}{ Rata-rata } & 7,26 & 0,44 \\
\hline
\end{tabular}


Tabel 5. Kualitas Air Bersih di Pipa Distribusi Pelanggan Industri

\begin{tabular}{|c|c|c|c|c|}
\hline \multirow{2}{*}{ No } & \multirow{2}{*}{ Hari Penelitian } & \multirow{2}{*}{ Lokasi Penelitian } & \multicolumn{2}{|c|}{ Parameter Pokok } \\
\cline { 3 - 5 } & & & PH & NTU \\
\hline \multirow{2}{*}{1} & Selasa, & Blok XII.1 & 7,54 & 2,00 \\
\cline { 3 - 5 } & 14 Juni 2011 & Blok XVI.1 & 7,56 & 2,24 \\
\hline \multirow{2}{*}{2} & Rabu, & Blok H.VI.3 & 7,32 & 2,24 \\
\cline { 3 - 5 } & 15 Juni 2011 & Blok V.1 & 7,41 & 2,42 \\
\hline
\end{tabular}

Pengamatan yang dilakukan dalam mengukur debit air bersih dilakukan pada lokasi produksi (instalasi pengolahan) dan lokasi distribusi (pipa distribusi). pengamatan dilakukan pada 3 hari kerja.

Tabel 6. Volume dan Debit Air Bersih di Instalasi Pengolahan WTP I

\begin{tabular}{|c|c|c|c|c|c|c|}
\hline \multirow{2}{*}{ No } & \multirow{2}{*}{$\begin{array}{c}\text { Hari } \\
\text { Penelitian }\end{array}$} & \multicolumn{5}{|c|}{ Produksi / Pengolahan } \\
\cline { 3 - 7 } & $\begin{array}{c}\text { Volume Air }\left(\mathrm{m}^{3}\right) \\
\text { Line-1 }\end{array}$ & Line-3 & $\begin{array}{c}\text { Line-1 \& } \\
\text { Line-2 }\end{array}$ & Line-3 & Total \\
\hline 1 & $\begin{array}{c}\text { Selasa } \\
14 \text { Juni 2011 }\end{array}$ & 7113 & 3661 & 282,26 & 145,27 & 427,53 \\
\hline 2 & $\begin{array}{c}\text { Rabu, } \\
\text { 15 Juni 2011 }\end{array}$ & 6813 & 1559 & 270,35 & 61,86 & 332,22 \\
\hline 3 & $\begin{array}{c}\text { Kamis, } \\
16 \text { Juni 2011 }\end{array}$ & 4329 & 3492 & 171,78 & 138,57 & 310,35 \\
\hline \multicolumn{7}{|c|}{ Rata-rata Total } \\
\hline
\end{tabular}

Keterangan :

1). Untuk volume air $\left(\mathrm{m}^{3}\right)$, diambil sampel tiap 7 jam sekali (per shift), peneliti hanya mengambil sampel shift 1 (7.30 s/d 14.30)

2). $1 \mathrm{~m}^{3}=1000$ liter

Tabel 7. Volume dan Debit Air Bersih di Pipa Distribusi WTP I

\begin{tabular}{|c|c|c|c|}
\hline \multirow{2}{*}{ No } & \multirow{2}{*}{$\begin{array}{c}\text { Hari } \\
\text { Penelitian }\end{array}$} & \multicolumn{2}{|c|}{ Pipa Distribusi } \\
\hline & & Volume Air $\left(\mathrm{m}^{3}\right)$ & Debit Air (liter/s) \\
\hline 1 & $\begin{array}{c}\text { Selasa, } \\
14 \text { Juni } 2011\end{array}$ & 7100 & 281,74 \\
\hline 2 & $\begin{array}{c}\text { Rabu, } \\
15 \text { Juni } 2011 \\
\end{array}$ & 6460 & 256,34 \\
\hline 3 & $\begin{array}{c}\text { Kamis, } \\
16 \text { Juni } 2011 \\
\end{array}$ & 7650 & 303,57 \\
\hline \multicolumn{3}{|c|}{ Rata-rata } & 280.55 \\
\hline
\end{tabular}

Keterangan : Debit air diambil melalui automatic flowmeter yang sudah tercantum nilai dari volume air dan debit air. 
Pengamatan terhadap kualitas air bersih dilakukan di tempat Instalasi Pengolahan Air (IPA) bersih di area WTP II kawasan Jababeka. Dalam hal ini pemeriksaan kualitas air bersih mengacu kepada parameter pokok (PH, warna, rasa/bau, dan Turbidity/Kekeruhan (NTU)) yang terdapat pada Permenkes RI No. 416 / Menkes / Per / IX / 1990 tentang Syarat-Syarat dan Pengawasan Kualitas Air. Untuk menentukan tingkat kualitas air bersih, dilakukan dengan 2 pemeriksaan, yaitu :

1) Pemeriksaan secara langsung

Untuk pemeriksaan langsung, pengambilan sampel air bersih guna mengukur tingkat PH dan NTU dilakukan di 2 tempat, yakni pada clarifier dan water supply pump (WSP). Pengambilan sampel ini dilakukan secara berkala (3x sehari) menggunakan alat pengukur derajat keasaman $(\mathrm{PH})$ dan NTU yaitu turbidimeter.

2) Pemeriksaan melalui hasil laboratorium

Untuk pemeriksaan melalui hasil laboratorium, tingkat kualitas air bersih dapat dilihat sehari setelah sampel air bersih diberikan, untuk kemudian dapat dianalisis perbandingannya dengan pemeriksaan secara langsung.

Tabel 8. Kualitas Air Bersih di Instalasi Pengolahan Air WTP II

\begin{tabular}{|c|c|c|c|c|c|c|}
\hline \multirow{3}{*}{ No } & \multirow{3}{*}{ Hari Penelitian } & \multirow{3}{*}{$\begin{array}{l}\text { Lokasi } \\
\text { Penelitian }\end{array}$} & \multicolumn{4}{|c|}{ Parameter Pokok } \\
\hline & & & \multicolumn{2}{|c|}{ PH } & \multicolumn{2}{|c|}{ NTU } \\
\hline & & & Lapangan & Laboratorium & Lapangan & Laboratorium \\
\hline \multirow{3}{*}{1} & \multirow{3}{*}{$\begin{array}{c}\text { Rabu, } \\
08 \text { Juni } 2011\end{array}$} & Clarifier-1 & 9,11 & 7,16 & 2,65 & 2,30 \\
\hline & & Clarifier-2 & 9,11 & 7,15 & 2,65 & 1,23 \\
\hline & & WSP & - & 7,17 & 1,50 & 0,26 \\
\hline \multirow{3}{*}{2} & \multirow{3}{*}{$\begin{array}{c}\text { Kamis, } \\
09 \text { Juni } 2011\end{array}$} & Clarifier-1 & 9,11 & 7,10 & 3,65 & 1,74 \\
\hline & & Clarifier-2 & 9,11 & 7,09 & 3,65 & 1,70 \\
\hline & & WSP & - & 7,14 & 1,48 & 0,26 \\
\hline \multirow{3}{*}{3} & \multirow{3}{*}{$\begin{array}{c}\text { Sabtu, } \\
11 \text { Juni } 2011\end{array}$} & Clarifier-1 & 8,46 & 7,07 & 3,16 & 1,96 \\
\hline & & Clarifier-2 & 8,46 & 7,02 & 3,16 & 1,72 \\
\hline & & WSP & - & 7,23 & 1,41 & 0,38 \\
\hline \multirow{3}{*}{4} & \multirow{3}{*}{$\begin{array}{c}\text { Minggu, } \\
12 \text { Juni } 2011\end{array}$} & Clarifier-1 & 9,26 & 7,20 & 3,47 & 3,77 \\
\hline & & Clarifier-2 & 9,26 & 7,07 & 3,47 & 3,15 \\
\hline & & WSP & - & 7,16 & 1,92 & 0,53 \\
\hline \multirow{4}{*}{5} & \multirow{3}{*}{$\begin{array}{c}\text { Senin, } \\
13 \text { Juni } 2011\end{array}$} & Clarifier-1 & 9,19 & 7,46 & 1,57 & 2,36 \\
\hline & & Clarifier-2 & 9,19 & 7,42 & 1,57 & 2,45 \\
\hline & & WSP & - & 7,13 & 1,74 & 0,47 \\
\hline & \multicolumn{3}{|c|}{ pH Rata-rata } & 7,16 & \multicolumn{2}{|c|}{0,995} \\
\hline
\end{tabular}


Tabel 8. menunjukkan tingkat kualitas air bersih di Instalasi pengolahan dengan $\mathrm{pH}$ dan Turbidity sebagai parameter pokoknya. Pengamatan dilakukan selama 5 hari pada shift 1 (08.30 s/d 14.30 WIB). Untuk Pengambilan sampel kualitas air bersih di area distribusi, diambil secara acak sampel air bersihnya sesuai dengan zona pelanggan. Air bersih yang dijadikan sampel kemudian dianalisis di laboratorium lingkungan.

Tabel 9. Kualitas Air Bersih di Pipa Distribusi Pelanggan Perumahan

\begin{tabular}{|c|c|c|c|c|}
\hline \multirow{2}{*}{ No } & \multirow{2}{*}{ Hari Penelitian } & \multirow{2}{*}{ Lokasi Penelitian } & \multicolumn{2}{|c|}{ Parameter Pokok } \\
\cline { 3 - 5 } & & & PH & NTU \\
\hline \multirow{2}{*}{1} & Rabu, & Jl. Jerapah (A) & 7,14 & 1,80 \\
\cline { 3 - 5 } & 08 Juni 2011 & Jl. Jerapah (B) & 7,14 & 3,06 \\
\hline \multirow{2}{*}{2} & Kamis, & Jl. Singa II & 7,33 & 2,57 \\
\cline { 3 - 5 } & 09 Juni 2011 & Jl. Menjangan V & 7,39 & 0,36 \\
\hline \multirow{2}{*}{3} & Sabtu, & ICT & 7,26 & 4,98 \\
\cline { 3 - 5 } & 11 Juni 2011 & Jl. Gardenia & 7,25 & 0,48 \\
\hline \multirow{2}{*}{4} & Senin, & Jl. Kasuari 19(B) & 7,12 & 0,27 \\
\cline { 3 - 5 } & 13 Juni 2011 & J. Merak 15(A) & 7,13 & 0,38 \\
\hline \multirow{2}{*}{ pH Rata-rata } & 7,22 & 1,73 \\
\hline
\end{tabular}

Pengukuran debit air bersih yang ada di WTP kawasan Jababeka menggunakan sistem otomatis melalui sensor yang terdapat dalam pipa pengolahan maupun pipa distribusi, peneliti hanya mencatat counter/volume air yang ditampung dalam instalasi pengolahan. Penelitian untuk mencari debit air ini dilakukan selama 5 hari pada shift 1 (09.00 WIB sampai dengan 11.30 WIB).

Tabel 10. Volume dan Debit Air Bersih di Instalasi Pengolahan WTP II

\begin{tabular}{|c|c|c|c|c|c|c|}
\hline \multirow{3}{*}{ No } & \multirow{3}{*}{$\begin{array}{c}\text { Hari } \\
\text { Penelitian }\end{array}$} & \multicolumn{5}{|c|}{ Produksi / Pengolahan } \\
\hline & & \multicolumn{2}{|c|}{ Volume Air $\left(\mathrm{m}^{3}\right)$} & \multicolumn{3}{|c|}{ Debit Air (liter/s) } \\
\hline & & Line-1 dan 2 & Line-3 & Liner-1 \& 2 & Line-3 & Total \\
\hline 1 & $\begin{array}{c}\text { Rabu, } \\
08 \text { Juni } 2011\end{array}$ & 2062 & 3020 & 81,82 & 119,84 & 201.66 \\
\hline 2 & $\begin{array}{c}\text { Kamis, } \\
09 \text { Juni } 2011\end{array}$ & 1992 & 2904 & 79,04 & 115,23 & 194.27 \\
\hline 3 & $\begin{array}{c}\text { Sabtu, } \\
11 \text { Juni } 2011\end{array}$ & 1627 & 2594 & 65,56 & 102,93 & 168.49 \\
\hline 4 & $\begin{array}{c}\text { Minggu, } \\
12 \text { Juni } 2011\end{array}$ & 1538 & 2342 & 61,03 & 92,93 & 153.96 \\
\hline 5 & $\begin{array}{c}\text { Senin, } \\
13 \text { Juni } 2011\end{array}$ & 1821 & 2678 & 72,5 & 106,26 & 178.76 \\
\hline \multicolumn{6}{|c|}{ Rata-rata Total } & 179,42 \\
\hline
\end{tabular}


Keterangan :

1). Untuk volume air $\left(\mathrm{m}^{3}\right)$, diambil sampel tiap 7 jam sekali (per shift), peneliti hanya mengambil sampel shift 1 (7.30 s/d 14.30)

2). $1 \mathrm{~m}^{3}=1000$ liter

Selain pemantauan pada instalasi pengolahan, pemantauan dilakukan juga di pipa distribusi yang nantinya akan dilakukan perbandingan tingkat debit air baik yang masuk (menuju intalasi pengolahan) maupun yang air bersih yang keluar (menuju ke pelanggan).

Tabel 11. Volume dan Debit Air Bersih di Pipa Distribusi Pelanggan Perumahan

\begin{tabular}{|c|c|c|c|c|c|c|c|c|}
\hline \multirow{3}{*}{ No } & \multirow{3}{*}{$\begin{array}{c}\text { Hari } \\
\text { Penelitian }\end{array}$} & \multicolumn{7}{|c|}{ Pipa Distribusi } \\
\hline & & \multicolumn{3}{|c|}{ Volume Air $\left(\mathrm{m}^{3}\right)$} & \multicolumn{4}{|c|}{ Debit Air (liter/s) } \\
\hline & & Line-1 & Line-2 & Line-3 & Line-1 & Line-2 & Line-3 & Total \\
\hline 1 & $\begin{array}{c}\text { Rabu, } \\
08 \text { Juni } 2011\end{array}$ & 1302 & 1331 & 810 & 51,67 & 52,82 & 32,14 & 136.63 \\
\hline 2 & $\begin{array}{c}\text { Kamis, } \\
09 \text { Juni } 2011\end{array}$ & 1321 & 1370 & 857 & 52,42 & 54,36 & 34 & 140.78 \\
\hline 3 & $\begin{array}{c}\text { Sabtu, } \\
11 \text { Juni } 2011\end{array}$ & 1360 & 1459 & 911 & 53,96 & 57,89 & 36,15 & 148.00 \\
\hline 4 & $\begin{array}{c}\text { Minggu, } \\
12 \text { Juni } 2011\end{array}$ & 1348 & 1476 & 929 & 53,49 & 58,57 & 36,86 & 148.92 \\
\hline 5 & $\begin{array}{c}\text { Senin, } \\
13 \text { Juni } 2011\end{array}$ & 1366 & 1398 & 843 & 54,20 & 55,47 & 33,45 & 143.12 \\
\hline & & & Rata-rat & total & & & & 143,49 \\
\hline
\end{tabular}

Berdasarkan pada kuesioner yang telah disebar kepada pelanggan perumahan. Maka kualitas air bersih di perumahan dapat ditentukan atau dianalisis dengan menggunakan distribusi frekuensi.

Tabel 12. Survey Kualitas Air Bersih WTP II Pada Pelanggan Perumahan

\begin{tabular}{|c|l|c|c|c|c|}
\hline \multirow{2}{*}{ Indikator } & \multicolumn{1}{|c|}{ Sub Indikator } & \multicolumn{3}{|c|}{ Analisis Data } \\
\cline { 2 - 3 } & \multicolumn{1}{|c|}{$\mathbf{F}_{\mathbf{1}}$} & $\%$ & $\mathbf{F}_{\mathbf{2}}$ & $\%$ \\
\hline \multirow{3}{*}{ KUALITAS } & $\begin{array}{l}\text { Tingkat Kekeruhan Air Bersih di } \\
\text { Kawasan perumahan }\end{array}$ & 23 & & 10 & \multirow{2}{*}{$\begin{array}{l}\text { Tingkat Rasa Bau dari air bersih } \\
\text { yang terdapat di perumahan }\end{array}$} \\
\cline { 2 - 3 } & $\begin{array}{l}\text { Tingkat warna yang ada pada air } \\
\text { bersih di perumahan }\end{array}$ & 26 & 77.78 & 7 & \\
\hline
\end{tabular}

Keterangan :

$F_{1} \quad$ : Pelanggan yang berpendapat kualitas air bersih bagus

$\mathrm{F}_{2} \quad$ : Pelanggan yang berpendapat kualitas air bersih kurang bagus 
Berdasarkan pada kuesioner yang telah disebar kepada pelanggan perumahan, kuantitas air bersih di perumahan yang dijadikan parameter adalah (volume air, debit air, dan distribusinya). Dari hasil survey yang didapat,. menunjukkan bahwa Pelanggan yang berpendapat kuantitas air bersih bagus $\left(F_{1}\right)$ adalah sekitar $46.56 \%$. Prosentase ini lebih kecil dibandingkan pelanggan yang berpendapat bahwa kuantitas air bersih kurang bagus $\left(F_{2}\right)$ sekitar $53.44 \%$. Hal ini dikarenakan masih terdapat keluhan dari pelanggan berkenaan dengan debit air dan distribusi aliran air ke perumahan.

Tabel 13. Survey Kualitas Air Bersih Pelanggan Industri dan Perumahan

\begin{tabular}{|c|l|c|c|}
\hline \multirow{2}{*}{ No } & \multirow{2}{*}{ Jenis Responden } & Kualitas Air Bagus & $\begin{array}{c}\text { Kualitas Air Kurang } \\
\text { Bagus }\end{array}$ \\
\cline { 3 - 4 } & & $\mathbf{7 7 , 7 8}$ & 22,22 \\
\hline 1 & Pelanggan Perumahan & 40 & $\mathbf{5 0}$ \\
\hline 2 & Pelanggan Industri & & \\
\hline
\end{tabular}

Dilihat dari hasil penelitian masih terdapat pelanggan yang merasa kualitas air bersih di perumahan kurang bagus. Pelanggan yang berpendapat air bersih di tempat tinggalnya kurang bagus, menyatakan bahwa baik itu tingkat kekeruhan, bau, dan warna masih perlu diperbaiki.

Mengacu pada Permenkes RI No. 416 / Menkes / Per / IX / 1990 tentang Syarat-Syarat dan Pengawasan Kualitas Air, untuk mengidentifikasi kekurangan yang terdapat pada kualitas air bersih di Kawasan Jababeka, maka dilakukan pengamatan di dua tempat, yakni WTP I dan WTP II. Masing - masing tempat diambil sampel air bersih pada bagian pengolahan dan distribusinya. Parameter pokok yang diamati adalah $\mathrm{pH}$ dan Kekeruhan (Turbidity) dengan satuan NTU (Nepnelometrik Turbidity Units).

Tabel 14. Perbandingan kualitas pH Air Bersih Kawasan Industri (WTP I) dan Perumahan (WTP II)

\begin{tabular}{|c|l|c|c|c|}
\hline \multirow{2}{*}{ No } & Tempat Pengamatan & $\begin{array}{c}|c| \\
\mathrm{pH} \mathrm{Syarat} \\
(6,5-8,5)\end{array}$ & $\begin{array}{c}\mathrm{pH} \text { (Instalasi } \\
\text { Pengolahan) }\end{array}$ & $\begin{array}{c}\mathrm{pH} \text { (Pipa } \\
\text { Distribusi) }\end{array}$ \\
\hline 1 & Kawasan Industri & 7 & 7,26 & 7,45 \\
\hline 2 & Kawasan Perumahan & 7 & 7,16 & 7,22 \\
\hline
\end{tabular}


Tabel 15. Perbandingan Kekeruhan/Turbidity Air Bersih Kawasan Perumahan dan Industri

\begin{tabular}{|c|c|c|c|c|}
\hline \multirow{2}{*}{ No } & Tempat Pengamatan & Minimum & $\begin{array}{c}\text { Instalasi } \\
\text { Pengolahan }\end{array}$ & $\begin{array}{c}\text { Pipa } \\
\text { Distribusi }\end{array}$ \\
\cline { 3 - 5 } & Kawasan Industri & 5 & 0,44 & 2,22 \\
\hline 1 & Kawasan Perumahan & 5 & 0,995 & 1,73 \\
\hline 2 & &
\end{tabular}

Tabel 16. Tingkat Kekeruhan/Tubidity Setelah Dilakukan Flushing di Pipa Distribusi Kawasan Industri

\begin{tabular}{|c|c|c|c|}
\hline \multirow{2}{*}{ No } & \multirow{2}{*}{ Tempat Flushing } & \multicolumn{2}{|c|}{ Tingkat Kekeruhan (NTU) } \\
\cline { 3 - 4 } & & NTU Maksimum & NTU real \\
\hline 1 & Blok F19-28 & 5 & 8,41 \\
\hline 2 & Blok E1-5B & 5 & 32,7 \\
\hline 3 & Blok L1-2 & 5 & 41,1 \\
\hline
\end{tabular}

. pH batas yang diizinkan : 6,5-8,5)

turbidity batas yang diizinkan : 5 .

Untuk kuantitas air bersih yang dihasilkan dari tempat pengolahan, baik pada WTP I maupun WTP II, menunjukkan debit air rata-rata yang cukup kencang, yaitu berkisar 356,7 liter/detik untuk WTP I dan 179,42 liter/detik untuk WTP II. Terjadi perbedaan pada debit air dikarenakan jumlah kebutuhan air bersih di industri lebih besar dibandingkan dengan kebutuhan air bersih di perumahan

Untuk kuantitas air bersih di Kawasan Jababeka, paramater yang menjadi acuan adalah volume air dan debit air. Pelanggan baik itu industri maupun perumahan yang disurvey memberikan pendapatnya mengenai kuantitas air bersih yang dihasilkan dari WTP I dan WTP II. Selanjutnya, dari hasil survey kemudian dianalisis tingkat kuantitasnya pada bagian pengelolaan (pengolahan dan distribusi).

Tabel 17. Survey Kuantitas Air Bersih Pelanggan Industri dan Perumahan

\begin{tabular}{|c|l|c|c|}
\hline \multirow{2}{*}{ No } & \multirow{2}{*}{ Jenis Responden } & \multicolumn{2}{|c|}{ Hasil Survey (\%) } \\
\cline { 3 - 4 } & & Kuantitas Air Bagus & $\begin{array}{c}\text { Kuantitas Air Kurang } \\
\text { Bagus }\end{array}$ \\
\hline 1 & Pelanggan Perumahan & 46,56 & $\mathbf{5 3 , 4 4}$ \\
\hline 2 & Pelanggan Industri & $\mathbf{4 0}$ & 30 \\
\hline
\end{tabular}


Dari tabel 17. menunjukkan bahwa masih banyak pelanggan perumahan yang menganggap kuantitas air bersih diperumahan kurang bagus $(53,44 \%)$. Hal ini didasarkan pada debit air yang terkadang kecil pada waktu-waktu tertentu (peak time) mengakibatkan debit air untuk pelanggan masih terasa kurang.

Tabel 18. Perbandingan Debit Air Bersih Kawasan Perumahan dan Industri

\begin{tabular}{|c|c|c|c|}
\hline \multirow{2}{*}{ No } & \multirow{2}{*}{ Tempat Pengamatan } & \multicolumn{2}{|c|}{ Debit Air Rata-Rata (liter/detik) } \\
\cline { 3 - 4 } & & Instalasi Pengolahan & Pipa Distribusi \\
\hline 1 & Kawasan Industri & 356,7 & 280,55 \\
\hline 2 & Kawasan Perumahan & 179,42 & 143,49 \\
\hline
\end{tabular}

Tabel 18. menunjukkan debit air rata-rata yang didapat selama 8 hari kerja. Dari hasil pengamatan menunjukkan bahwa debit air yang dihasilkan kawasan industri lebih besar dibandingkan dengan kawasan perumahan. Hal ini disebabkan kebutuhan pelanggan industri terhadap air bersih lebih banyak dibandingkan dengan air bersih.

\section{KESIMPULAN}

Berdasarkan hasil studi dan penelitan tentang pengelolaan air bersih di Kawasan Jababeka Kabupaten Bekasi, maka diperoleh kesimpulan sebagai berikut:

1. Dari hasil identifikasi ditempat pengolahan air bersih, menunjukkan bahwa, tingkat kualitas dan kuantitas air bersih di Instalasi Pengolahan air sudah memenuhi kebutuhan/ sesuai dengan persyaratan yang ditentukan. Baik di WTP | dan WTP || menunjukkan tingkat kekeruhan/turbidity dan tingkat pH yang normal dan sesuai dengan Permenkes RI No. 416 / Menkes / Per / IX / 1990 (nilai pH diizinkan : 6,5-8,5 dan batas maksimum kekeruhan/turbidity : 5 NTU).

2. Dari hasil identifikasi di area distribusi air bersih, kualitas air di area pelanggan industri menunjukkan peningkatan kekeruhan, ditambah pada saat pelaksanaan flushing, air bersih menunjukkan tingkat kekeruhan yang amat tinggi, hal ini berdampak secara langsung terhadap air bersih yang diterima pelanggan industri. Kenyataan dilapangan, pelanggan industri mengeluhkan tingginya tingkat kekeruhan yang timbul kurang lebih 3 hari setelah pelaksanaan flushing. Selama masa flushing, air bersih yang ada mencapai tingkat kekeruhan 41,1 NTU (batas maksimum : 5 NTU). Sementara itu, untuk kualitas air bersih di area pelanggan perumahan, juga menunjukkan peningkatan kekeruhan/turbidity dibandingkan 
yang terdapat dari hasil pengolahan $(\mathrm{pH}: 0,44 \rightarrow \mathrm{pH}: 2,22)$. Dari segi kuantitas, debit air yang dihasilkan dari WTP I maupun WTP || mengalami penurunan dibandingkan dengan tempat pengolahan. Dari hasil pengamatan, debit air rata-rata di WTP I dan WTP || menunjukkan angka 280,55 Itr/dtk dan 143,49 Itr/dtk, hal ini tentu dapat mengurangi pasokan air bersih ke pelanggan. Untuk pengamatan pada area distribusi, berdasarkan hasil pengamatan dapat disimpulkan bahwa tingkat kualitas maupun kuantitas kurang memenuhi kebutuhan pelangganyan. Hal yang menyebabkan terjadinya penurunan tingkat kualitas dan kuantitas pada pipa distribusi :

a. Jaringan pipa yang lebih panjang dan luas memerlukan sistem perawatan yang intensif.

b. sistem flushing/blowdown yang kurang terkordinasi, mengakibatkan kotoran masuk kedalam pipa air bersih

c. Kualitas pipa yang menurun (dipakai sejak tahun 1989) memerlukan penggantian ulang.

3. Dari hasil survey kepuasan pelanggan air bersih, untuk kualitas air bersih, sebanyak $\mathbf{7 7 , 7 8 \%}$ responden perumahan menyatakan kualitas air yang dihasilkan sudah sesuai dengan kebutuhan pelanggan / untuk keperluan sehari-hari. Sementara itu, sebanyak $\mathbf{5 0} \%$ responden industri berpendapat kualitas air bersih yang dihasilkan belum memenuhi kebutuhan, masih terjadi kekeruhan yang tinggi pada pipa distribusi, sehingga berdampak pada kualitas air yang sampai pada pelanggan. Dari segi kuantitas, sebanyak $53,44 \%$ responden perumahan menyatakan debit air yang dihasilkan belum memenuhi kebutuhan, hal ini disebabkan terjadinya penurunan debit air pada saat jam sibuk (peak time) sehingga pelanggan merasakan terjadinya penurunan debit air. Sementara itu, sebanyak $40 \%$ responden industri menyatakan debit air yang dihasilkan sudah sesuai kebutuhan, baik untuk proses produksi maupun keperluan sehari-hari.

\section{DAFTAR PUSTAKA}

Arikunto, Suharsimi. 1998. Prosedur Penelitian. Jakarta: PT. Rineka Cipta.

Blogspot.2010.Kuesioner Penelitian.[Terhubung Berkala]

http:// tesis-petrus.tk/macam-macam kuesioner penelitian. [10 Juni 2011].

Darmasetiawan, Martin. Teori dan Perencanaan Instalasi Pengolahan Air. Jakarta: Ekamitra Engineering. 
Dinas Kesehatan Republik Indonesia.1990. Peraturan Menteri Kesehatan No. 416 Tahun 1990 Tentang : Syarat-syarat Dan Pengawasan Kualitas Air. Jakarta: Pemerintah Republik Indonesia.

Dinas Industri dan Perdagangan Republik Indonesia.1996. Keputusan Presiden Republik Indonesia Nomor 41 Tahun 1996 Tentang Kawasan Industri.Jakarta: Pemerintah Pusat Republik Indonesia.

Dinas Kesehatan Republik Indonesia.2006. Peraturan Pemerintah Republik Indonesia Nomor 82 Tahun 2001 Tentang Pengelolaan Kualitas Air Dan Pengendalian Pencemaran Air . Jakarta: Pemerintah Pusat Republik Indonesia.

Hartono, Djoko Mulyono. 2007. Pengaruh Perubahan Karakteristik Air Baku Air Permukaan Terhadap Keberlanjutan Penyediaan Air Minum (Studi Kasus Aspek Air Baku, Teknologi, Sosial Ekonomi Pada Bangunan IPA Buaran, Pulo Gadung dan Pejompongan)[Disertasi]. Jakarta: Fakultas Teknik, Jurusan Teknik Sipil, Pascasarjana Universitas Indonesia.

Jababeka.2010.Peta.Residence.WTP.[Terhubung Berkala] http://www.jababeka.com/city/8/masterplan. [11 Juli 2011]

Nur Fajri A, Mochtar H. 2007. Evaluasi Desain Instalasi Pengolahan Air PDAM Ibu Kota Kecamatan Prambanan Kabupaten Klaten. Vol.3 No.2. ISSN 1907-187X.

Perdana Adiarsa, Tegar Eka dan Suprihanto Notodarmojo. 2007. Capacity Evaluation at Water Treatment Plant 1 PT. Jababeka Infrastruktur, Tbk.

Razif, Mohammad. 2006. Aplikasi Teknologi Produksi Bersih di Instalasi Pengolahan Air Minum (Studi Kasus PDAM Surabaya.[skripsi]. Surabaya : Fakultas Teknik, Jurusan Teknik Lingkungan, Institut Teknologi Sepuluh November (ITS).

Riani, Jenny. 2010. Studi Dampak Pengoperasian Busway Pada Perumahan Metro Pondok Indah Koridor VIII [Skripsi]. Jakarta : Fakultas Teknik, Jurusan Teknik Sipil, Universitas Negeri Jakarta.

Sunarjo, Lusiawati. 2007. Kajian Pengembangan Eco-Industrial Park (Kasus: Kawasan Industri Jababeka Kabupaten Bekasi)[tesis]. Jakarta : Program Studi IImu Lingkungan, Program Pascasarjana Universitas Indonesia.

Utari, Uun. 2010. Perencanaan Perbaikan Tanggul Kali Bekasi Sebagai Alternatif Pengendalian Banjir di Kota Madya Bekasi [Skirpsi]. Jakarta : Fakultas Teknik, Jurusan Teknik Sipil, Universitas Negeri Jakarta. 
Wibawa B.et al. 2004. Pedoman Penulisan Skripsi, Pelaksanaan Ujian Skripsi, Karya Inovatif Produktif Komprehensif, dan Tugas Akhir. Jakarta: Fakultas Teknik Universitas Negeri Jakarta.

Wikipedia.2010.Basa dan Asam pH.[Terhubung Berkala]

http://id.wikipedia.org/wiki/PH.[11 Juli 2011].

Wikipedia.2010. Pengertian-pengelolaan/.[Terhubung Berkala]

http://id.shvoong.com/writing-and-speaking/presenting/2108155-pengertian-pengelolaan [28 Juli 2011]

Yuliarmi, Ni Nyoman, Putu Riyasa. 2007. Analisis Faktor-Faktor Yang Mempengaruhi Kepuasan Pelanggan Terhadap Pelayanan Pdam Kota Denpasar.[Tesis].Fakultas Ekonomi, Jurusan Ilmu Ekonomi, Universitas Udayana, Denpasar. 